\title{
PERLINDUNGAN PASIEN DALAM PELAYANAN KESEHATAN OLEH FASILITAS KESEHATAN BPJS DI KOTA BANDUNG DIHUBUNGKAN DENGAN UNDANG-UNDANG NO. 24 TAHUN 2011 TENTANG BADAN PENYELENGGARA JAMINAN SOSIAL DAN PERATURAN MENTERI KESEHATAN NO. 71 TAHUN 2013 TENTANG PELAYANAN KESEHATAN PADA JAMINAN KESEHATAN NASIONAL
}

\author{
Balqis Mar'atus Sholehah -1 , U. Sudjana ${ }^{2}$, Aam Suryaman -2 \\ Mahasiswa Fakultas Hukum, Universitas Padjadjaran \\ Program Studi Sarjana Ilmu Hukum, Fakultas Hukum Universitas Padjadjaran
}

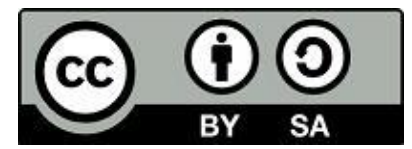

DOI: http://dx.doi.org/10.33603/hermeneutika.v3i2

Diterima: 20 Desember 2019; Direvisi: 26 Januari 2020; Dipublikasikan: Februari 2020

\begin{abstract}
Abstrak: Badan Penyelenggara Jaminan Sosial (BPJS) Kesehatan merupakan badan hukum publik dibentuk dengan Undang-Undang untuk menyelenggarakan program jaminan sosial nasional. Faktanya dalam pemberian pelayanan kesehatan oleh salah satu fasilitas kesehatan yang berada di Kota Bandung yaitu Rumah Sakit, masih terdapat pasien peserta BPJS yang belum terpenuhi haknya untuk mendapatkan pelayanan kesehatan yang optimal. Permasalahan yang sering terjadi yaitu kelangkaan obat yang telah dijamin dalam Daftar Obat Esensial (DOEN) serta keterlambatan pelayanan kesehatan oleh petugas kesehatan di salah satu Rumah Sakit X di Kota Bandung. Penelitian ini bertujuan untuk mendapatkan gambaran tentang pemberian pelayanan kesehatan oleh fasilitas kesehatan yang bekerjasama dengan BPJS dan perlindungan terhadap pasien peserta BPJS Kesehatan. Penelitian ini disusun dengan menggunakan metode pendekatan yuridis normatif yaitu metode penelitian yang difokuskan untuk mengkaji penerapan kaidah-kaidah atau norma-norma dalam hukum positif yang kemudian dianalisis secara normatif kualitatif. Hasil penelitian dapat disimpulkan bahwa pemberian pelayanan kesehatan terhadap pasien peserta BPJS di rumah sakit dan puskesmas belum sepenuhnya memadai, hal ini dapat dilihat dari tidak terpenuhnya hak yang dimiliki pasien untuk medapatkan obat dan pelayanan kesehatan sesuai dengan kebutuhan pasien, sesuai dengan Pasal 13 UU BPJS memiliki kewajiban memberikan manfaat kepada seluruh peserta untuk mendapatkan hak dan memenuhi kewajibannya, serta Permenkes No.71 Tahun 2013 Pasal 13 ayat 1 bahwa manfaat jaminan kesehatan, mencakup pelayanan promotif, preventif, kuratif, dan rehabilitatif, termasuk pelayanan obat, alat kesehatan, dan bahan medis habis pakai. Hal ini Rumah Sakit bertanggung jawab atas kerugian yang ditimbulkan akibat pelayanan kesehatan yang diberikan oleh petugas kesehatan terhadap pasien peserta BPJS.
\end{abstract}

Kata Kunci: Pelayanan Kesehatan, Fasilitas Kesehatan, Badan Penyelenggara Jaminan Sosial, Perlindungan Pasien.

\footnotetext{
${ }^{1}$ Balqis Mar'atus Sholehah $[-$

Email: balqismshale@gmail.com
} 


\section{PENDAHULUAN}

Kesejahteraan sosial merupakan bangunan dasar bagi setiap negara dalam membangun dan memberikan perlindungan kepada segenap bangsanya. Setiap negara sudah tentu mempunyai cita-cita buat apa negara itu didirikan. Bagi Indonesia, citacita tersebut adalah mewujudkan kesejahteraan yang berkeadilan sosial. Sesuai dengan amanat Undang-Undang Negara Republik Indonesia Tahun 1945 amandemen ke IV pada alinea keempat, yang tertulis "Melindungi segenap bangsa Indonesia dan seluruh tumpah darah

Indonesia dan untuk memajukan kesejahteraan umum, mencerdaskan kehidupan bangsa, dan ikut melaksanakan

ketertiban dunia yang berdasarkan kemerdekaan, perdamaian abadi, dan keadilan sosial."

Kesehatan merupakan hak asasi manusia dan salah satu unsur kesejahteraan umum yang harus diwujudkan sesuai dengan cita-cita bangsa Indonesia yang dapat terwujud melalui pengembangan sistem jaminan sosial melalui lembaga-lembaga yang khusus mengelola berbagai skema perlindungan sosial. Dalam sistem kesehatan nasional harus diperhatikan mengenai peran serta masyarakat yang digambarkan sebagai akibat prinsip bahwa masalah kesehatan adalah tugas dan tanggung jawab bersama antara pemerintah dan masyarakat. ${ }^{1}$ Badan Penyelenggara Jaminan Sosial (BPJS) Kesehatan yang merupakan badan hukum publik dibentuk

dengan Undang-Undang untuk menyelenggarakan program jaminan sosial nasional berdasarkan Undang-Undang Nomor 40 Tahun 2004 tentang Sistem Jaminan Sosial Nasional bertujuan sebagai bentuk perlindungan sosial agar setiap peserta terjamin untuk memenuhi kebutuhan dasar hidup minimal yang layak agar terwujud kesejahteraan sosial yang

${ }^{1}$ Veronika Komalawati, Peranan Informed Consent Dalam Transaksi Terapeutik, Bandung:PT Citra Aditya Bakti, 2002, hlm. 3. berkeadilan bagi seluruh rakyat. Dalam melaksanakan program jaminan sosial, Pasal 13 UU BPJS menyebutkan bahwa BPJS Kesehatan memiliki kewajiban untuk memberikan manfaat kepada seluruh peserta sesuai dengan Undang-Undang yang berlaku, memberikan informasi kepada

peserta mengenai prosedur untuk mendapatkan hak dan memenuhi kewajibannya, maka program penyelenggaraan sistem jaminan sosial akan berhasil apabila dalam penyelenggaraan program jaminan kesehatan, tersedianya sarana kesehatan yang memadai karena sangat penting sebagai pertimbangan kelayakan program jaminan sosial atau

bagaimana kecukupan jumlah dan kemampuan sarana kesehatan dapat

menjamin penyelenggaraan program jaminan kesehatan yang efisien agar kelangsungan hidup program terjamin. ${ }^{2}$

Pelayanan kesehatan tidak hanya meliputi kegiatan atau aktivitas professional di bidang pelayanan kuratif dan preventif untuk kepentingan perseorangan, tetapi juga meliputi lembaga pelayanannya, sistem

kepengurusannya, pembiayaannya, pengelolaannya, tindakan pencegahan umum dan penerangan. ${ }^{3}$ Hal ini sebagai lembaga pemerintahan yang menjalankan fungsi pemerintahan di bidang pelayanan umum, BPJS kesehatan berkewajiban memberikan informasi kepada fasilitas kesehatan berkaitan dengan kepesertaan, prosedur pelayanan, pembayaran dan proses kerja sama dengan BPJS Kesehatan. Bentuk pelayanan kesehatan bagi peserta yang dijamin oleh BPJS Kesehatan terdiri atas pelayanan kesehatan tingkat pertama, pelayanan kesehatan rujukan tingkat lanjutan yang terdiri atas pelayanan kesehatan tingkat kedua (spesialistik) dan pelayanan kesehatan tingkat ketiga

2 Sulastomo, Sistem Jaminan Sosial Nasional Mewujudkan Amanat Konstitusi, Jakarta:PT Kompas Media Nusantara, 2011, hlm.10

${ }^{3}$ Veronica Komalawati, Op.Cit , hlm 78. 
(subspesialistik) dan pelayanan kesehatan lain yang ditetapkan oleh Menteri. Adapun hak peserta yang dijamin oleh BPJS yaitu memperoleh manfaat dan informasi tentang hak dan kewajiban serta prosedur pelayanan kesehatan sesuai dengan ketentuan yang berlaku dan mendapatkan pelayanan kesehatan di fasilitas kesehatan yang bekerja dengan BPJS. ${ }^{4}$ Faktanya dalam pemberian pelayanan kesehatan oleh salah satu fasilitas kesehatan yang berada di Kota Bandung yaitu Rumah Sakit, masih terdapat pasien peserta BPJS yang belum terpenuhi haknya untuk mendapatkan pelayanan kesehatan yang optimal. Salah satu permasalahan yang sering terjadi yaitu kelangkaan obat sulfasalazine yaitu sistem kekebalan tubuh menyerang sel-sel sehat dalam tubuh yang dikonsumsi oleh penderita penyakit autoimmune. Kelangkaan ini terjadi di Rumah Sakit Hasan Sadikin Kota Bandung, hal tersebut oleh Rumah

Sakit yang bersangkutan menyatakan kekosongan. 5 Tak hanya itu, kasus kedua yaitu terdapat pasien yang menderita penyakit thalassemia minor, sebagai peserta BPJS yang sedang mengandung sekitar 32 minggu kesulitan mendapatkan obat deferoxamine yaitu obat yang juga dapat digunakan untuk menghilangkan zat besi pada pasien dengan kadar zat besi yang tinggi, disebabkan oleh banyaknya transfusi darah dan obat ini bekerja dengan mengikat zat besi berlebih pada tubuh juga membantu ginjal dan kandung empedu membuang kelebihan zat besi. Hal ini berkaitan dengan kondisi calon ibu karena anak yang akan lahir kelak membutuhkan Air Susu Ibu. ${ }^{6}$ demikian juga mengenai kecepatan pelayanan kesehatan di RSUD Ujung

4 "Hak dan Kewajiban", https://bpiskesehatan.go.id/bpjs/index.php/pages/detail/2017/ 27, diakses pada 10 Juli 2019, 15:18 WIB

5 "Kelangkaan Obat Sulfalazine di RS negara", https://www.lapor.go.id/laporan/detil/kelangkaanobat-sulfasalazine-di-rs-negara, diakses pada $18 \mathrm{Juli}$ 2019, 9:15 WIB.

6 "Keberadaan Obat Deferoxamine Yang Langka", https://www.lapor.go.id/profil/1776614, diakses pada 18 Juli 9:19 WIB.
Berung terdapat pasien yang sudah 3 hari ngantri dari sejak jam 4 pagi tetapi tak kunjung mendapat nomor antrian karena kehabisan kuota. ${ }^{7}$

Pada kasus tersebut, dapat mengakibatkan kerugian bagi pasien, sebab sebagai pasien BPJS memiliki hak untuk mendapatkan pelayanan kesehatan di fasilitas kesehatan yang bekerjasama dengan BPJS Kesehatan, salah satunya dengan pelayanan kesehatan berupa penyediaan obat sebagai bentuk pelayanan kesehatan kuratif. Berdasarkan hal tersebut maka perlu diperhatikan terkait perlindungan terhadap pasien peserta BPJS untuk menjamin pemberian pelayanan kesehatan oleh salah satu fasilitas kesehatan di Kota Bandung.

\section{TINJAUAN PUSTAKA \\ a. Tinjauan Umum Tentang Pelayanan Kesehatan}

Menurut Azrul Anwar bahwa salah satu subsistem dalam sistem kesehatan ialah subsistem pelayanan kesehatan. ${ }^{8}$ Pelayanan kesehatan merupakan hak setiap orang yang dijamin dalam Undang-Undang Dasar 1945 untuk melakukan upaya peningkatan derajat kesehatan baik perseorangan, maupun

kelompok atau masyarakat secara keseluruhan. ${ }^{9}$ Menurut Levey dan Loomba pelayanan kesehatan ialah setiap upaya yang diselenggarakan secara sendiri atau secara bersama-sama dalam suatu organisasi untuk memelihara dan meningkatkan kesehatab, mencegah dan menyembuhkan penyakit serta memulihkan kesehatan perorangan,

keluarga, kelompok dan ataupun masyarakat. ${ }^{10}$ Untuk dapat disebut pelayanan kesehatan yang baik, harus

\footnotetext{
7 "Pelayanan RSUD", https://www.lapor.go.id/laporan/detil/pelayananrsud-26, diakses pada 31 Juli 2019, 10:27 WIB.

8 Azrul Anwar, Pengantar Administrasi Kesehatan, Jakarta:Binarupa Aksara, 2010, hlm. 42

${ }^{9}$ Veronika Komalawati, Op.Cit, hlm. 77. 
memiliki berbagai persyaratan pokok, yaitu: ${ }^{11}$

a. Tersedia dan berkesinambungan

b. Dapat diterima dan wajar

c. Mudah dicapai

d. Mudah dijangkau

e. Bermutu

Berdasarkan Pasal 52 dan Pasal 53 Undang-Undang Kesehatan membagi 2 jenis pelayanan kesehatan yaitu:

a. Pelayanan kesehatan perseorangan ditujukan untuk menyembuhkan penyakit dan memulihkan kesehatan perseorangan dan keluarga. Disebut juga pelayanan kesehatan yang termasuk dalam kelompok pelayanan kedokteran (medical services) ditandai dengan cara pengorganisasian yang dapat bersifat sendiri atau secara bersama-sama dalam satu organisasi, tujuan utamanya untuk menyembuhkan penyakit dan memulihkan kesehatan, serta sasarannya terutama untuk peseorangan dan keluarga. ${ }^{12}$

b. Pelayanan kesehatan masyarakat ditujukan untuk memelihara dan meningkatkan kesehatan serta mencegah penyakit suatu kelompok dan masyarakat.

Pelayanan kesehatan sebagaimana dimaksud diatas meliputi kegiatan dengan pendekatan promotif, preventif, kuratif dan rehabilitatif. Definisi pelayanan kesehatan tersebut dijelaskan secara jelas dalam Pasal 1 Ketentuan Umum Undang-Undang Kesehatan, yaitu:

1) Pelayanan kesehatan promotif adalah suatu kegiatan dan/atau serangkaian kegiatan pelaynan kesehatan yang lebih mengutamakan kegiatan yang bersifat promosi kesehatan.

2) Pelayanan kesehatan preventif adalah suatu kegiatan pencegahan terhadap suatu masalah kesehatan/penyakit.
3) Pelayanan kesehatan kuratif adalah suatu kegiatan dan/atau serangkaian kegiatan pengobatan yang ditujukan untukpenyembuhanpenyakit,

pengurangan penderitaan akibat penyakit, pengendalian penyakit, atau pengendalian kecacatan agar kualitas penderita dapat terjaga seoptimal mungkin.

4) Pelayanan kesehatan rehabilitatif adalah kegiatan dan/atau serangkaian kegiatan untuk mengembalikan bekas penderita ke dalam masyarakat sehingga dapat berfungsi lagi sebagai anggota masyarakat yang berguna untuk dirinya dan masyarakat semaksimal mungkin sesuai dengan kemampuannya.

Mengenai hak peserta BPJS dijelaskan sebagai berikut: ${ }^{13}$

a. Mendapatkan kartu peserta sebagai identitas peserta untuk memperoleh pelayanan kesehatan.

b. Memperoleh manfaat dan informasi tentang hak dan

kewajiban serta prosedur pelayanan kesehatan sesuai dengan ketentuan yang berlaku.

c. Mendapatkan pelayanan kesehatan di fasilitas kesehatan yang bekerja dengan BPJS Kesehatan, dan

d. Menyampaikan keluhan/pengaduan, kritik dan saran secara lisan atau tertulis kepada BPJS Kesehatan.

Permenkes Nomor 71 Tahun 2013

dalam Pasal 23 ayat 1 tertera mengenai hak pasien untuk mendapatkan pelayanan obat, alat kesehatan dan bahan medis habis pakai yang dibutuhkan sesuai dengan indikasi medis.

\section{b. Tinjauan Umum Tentang Fasilitas Kesehatan}

Menurut Peraturan Menteri Kesehatan Nomor 71 Tahun 2013 Pasal 1

\footnotetext{
${ }^{13}$ https://bpjs-

kesehatan.go.id/bpjs/index.php/pages/detail/2017/ 27, diakses pada 13 September 2019, 7:33 WIB.
} 
Angka 5 menjelaskan pengertian fasilitas kesehatan sebagai berikut:

"Fasilitas Kesehatan adalah fasilitas pelayanan kesehatan yang digunakan untuk menyelenggarakan upaya pelayanan kesehatan perorangan, baik promotif, preventif, kuratif maupun rehabilitative yang dilakukan oleh Pemerintah, Pemerintah Daerah dan/atau Masyarakat. Sebagai penyelenggara pelayanan kesehatan fasilitas kesehatan meliputi semua fasilitas kesehatan yang bekerja sama dengan BPJS Kesehatan tingkat pertama dan fasilitas kesehatan rujukan tingkat lanjutan. Mengenai fasilitas kesehatan tingkat pertama dapat berupa: ${ }^{14}$

1. puskesmas atau yang setara;

2. praktik dokter;

3. praktik dokter gigi;

4. klinik pratama atau yang setara; dan

5. Rumah Sakit Kelas D Pratama atau yang setara.

Fasilitas kesehatan rujukan tingkat lanjutan berupa:

a. klinik utama atau yang setara;

b. rumah sakit umum; dan

c. rumah sakit khusus.

Fasilitas kesehatan memiliki tingakatan pelayanan yang terdiri atas:

1) Fasilitas Pelayanan Kesehatan tingkat pertama yang memberikan pelayanan kesehatan dasar;

2) Fasilitas Pelayanan Kesehatan tingkat kedua yang memberikan pelayanan kesehatan spesialistik;dan

3) Fasilitas Pelayanan Kesehatan tingkat ketiga yang memberikan pelayanan kesehatan subspesialistik.

Dalam hal fasilitas kesehatan tingkat kedua dan tingkat ketiga dapat memberikan pelayanan yang diberikan oleh fasilitas pelayanan kesehatan tingkat dibawahnya. Pasal 12 Peraturan Menteri Kesehatan Nomor 71 Tahun 2013 menjelaskan mengenai hak fasilitas kesehatan paling sedikit terdiri atas:

\footnotetext{
14 Peraturan Menteri Kesehatan Nomor 71 Tahun

$46 \quad \begin{aligned} & \text { Hermeneutika: Jurnal Ilmu Hukum Vol. } \\ & \text { 4, No. 1, Februari } 2020\end{aligned}$
}

a) mendapatkan informasi tentang kepesertaan, prosedur pelayanan, pembayaran dan proses kerjasama dengan BPJS Kesehatan; dan

b) menerima pembayaran klaim atas pelayanan yang diberikan kepada Peserta paling lambat 15 (lima belas) hari kerja sejak dokumen klaim diterima lengkap.

Kewajiban fasilitas kesehatan paling sedikit terdiri atas:

1. memberikan pelayanan kesehatan kepada Peserta sesuai ketentuan yang berlaku; dan

2. memberikan laporan pelayanan sesuai waktu dan jenis yang telah disepakati.

Rumah sakit sebagai salah satu faskes merupakan organ yang mempunyai kemandirian untuk melakukan hubungan hukum dengan penuh tanggung jawab, dalam hal demikian rumah sakit bukan merupakan "persoon" yang terdiri dari manusia ("sebagai naturlijk persoon"), melainkan rumah sakit diberi kedudukan hukum sebagai "persoon" dan oleh karenanya merupakan "rechtpersoon" karena itu pula rumah sakit dibebani hak dan kewajiban menurut hukum. ${ }^{15}$

Ruang lingkup tanggung jawab rumah sakit juga meliputi: ${ }^{16}$

1. Tanggung jawab Perdata

Hubungan hukum yang terjalin antara rumah sakit dengan pasien dalam perspektif hukum perdata merupakan hubungan kontrakstual yang menimbulkan hak dan kewajiban pada masing-masing pihak.

2. Tanggung Jawab Pidana

Pertanggungjawaban pidana dibebankan pada tenaga kesehatan yang melakukan kesalahan saat melaksanakan tugas pelayanan kesehatan di rumah sakit.

3. Tanggung Jawab Administrasi

15 Hermien Hadiati Koeswadji, Hukum Untuk Perumahsakitan, Bandung: PT. Citra Aditya Bakti, 2002, hlm. 89

16 idem. 
Tanggung jawab rumah sakit dalam ruang lingkup hukum administrasi dinilai dari persyaratan pendirian sampai dengan kegiatan penyelenggaraannya untuk melaksanakan pelayanan kesehatan kepada masyarakat.

\section{c. Tinjauan Umum Tentang Badan Penyelenggara Jaminan Sosial}

Dalam Pasal 1 angka 1 UU BPJS menjelaskan sebagai berikut:

"Badan Penyelenggara Jaminan Sosial (BPJS) adalah badan hukum yang dibentuk untuk menyelenggarakan program jaminan sosial." Badan Penyelenggara Jaminan Sosial (BPJS) adalah badan hukum publik yang dibentuk untuk menyelenggarakan program jaminan sosial. BPJS terdiri dari BPJS Kesehatan dan BPJS Ketenagakerjaan.

Dalam melaksanakan tugas diatas, BPJS berwenang untuk:

a. menagih pembayaran Iuran;

b. menempatkan Dana Jaminan Sosial untuk investasi jangka pendek dan jangka panjang dengan mempertimbangkan aspek likuiditas, solvabilitas, kehatihatian, keamanan dana, dan hasil yang memadai;

c. melakukanpengawasandan

pemeriksaan atas kepatuhan

Peserta dan Pemberi Kerja dalam memenuhi kewajibannya sesuai denganketentuanperaturan perundang-undangan jaminan sosial nasional;

d. membuat kesepakatan dengan fasilitas kesehatan mengenai besar pembayaran fasilitas kesehatan yang mengacu pada standar tarif yang ditetapkan oleh Pemerintah;

e. membuat atau menghentikan kontrak kerja dengan fasilitas kesehatan;

f. mengenakan sanski administrative kepada Peserta atau Pemberi Kerja yang tidak memenuhi

kewajibannya;

g. melaporkan Pemberi Kerja kepada instansi yang berwenang Iuran atau dalam memenuhi kewajiban lain sesuai dengan ketentuan peraturan perundang-undangan; dan

h. melakukan kerja sama dengan pihak lain dalam rangka penyelenggaraan program Jaminan Sosial.

Selanjutnya berdasarkan Pasal 13 UU BPJS, untuk melaksanakan tugastugasnya, BPJS memiliki kewajiban yaitu:

1) memberikan nomor identitas tunggal kepada Peserta;

2) mengembangkan asset Dana Jaminan Sosial dan asset BPJS untuk sebesarbesarnya kepentingan Peserta;

3) memberikan informasi melalui media massa cetak dan elektronik mengenai kinerja, kondisi keuangan, serta kekayaan dan hasil pengembangannya;

4) memberikan Manfaat kepada seluruh Peserta sesuai dengan UndangUndang tentang Sistem Jaminan Sosial Nasional;

5) memberikan informasi kepada Peserta mengenai hak dan kewajiban untuk mengikuti ketentuan yang berlaku;

6) memberikan informasi kepada Peserta mengenai prosedur untuk mendapatkan hak dan memenuhi kewajibannya;

7) memberikan informasi kepada Peserta mengenai saldo jaminan hari tua dan pengembangannya 1 (satu) kali dalam 1 (satu) tahun;

8) memberikan informasi kepada Peserta mengenai besar hak pensiun 1 (satu) kali dalam 1 (satu) tahun;

9) membentuk cadangan teknis sesuai dengan standar praktik aktuaria yang lazim dan berlaku umum;

10) melakukan pembukuan sesuai dengan standar akuntansi yang 
berlaku dalam penyelenggaraan

Jaminan Sosial; dan

11) melaporkan pelaksanaan setiap program, termasuk kondisi keuangan, secara berkala 6 (enam) bulan sekali kepada Presiden dengan tembusan kepada DJSN.

\section{PEMBAHASAN DAN ANALISIS}

a. Pemberian pelayanan obat dan kecepatan pelayanan oleh fasilitas kesehatan yang bekerjasama dengan BPJS di Kota Bandung berdasarkan Undang-Undang Nomor 24 Tahun 2011 dan Peraturan Menteri Kesehatan Nomor 71 Tahun 2013 Tentang Pelayanan Kesehatan pada Jaminan Kesehatan Nasional

Upaya kesehatan pada dasarnya sesuai dengan standar pelayanan minimal kesehatan dan pelaksanaannya harus mendahulukan pertolongan keselamatan nyawa pasien dibanding kepentingan lainnya. Satu-satunya badan asuransi kesehatan yang menyelenggarakan sistem jaminan sosial nasional yaitu Badan Penyelenggara Jaminan Sosial (BPJS) yang mulai beroperasi pada tanggal 1 Januari

2014 sebagai salah satu bentuk perlindungan sosial untuk menjamin seluruh rakyat agar dapat memenuhi kebutuhan dasar hidupnya yang layak berkaitan dengan kesehatan. Program jaminan kesehatan ini diselenggarakan sesuai dengan prinsip asuransi sosial. Asuransi sosial merupakan asuransi yang didirikan dan dikelola oleh pemerintah yang bersifat wajib untuk semua penduduk termasuk orang asing yang bekerja paling singkat 6 (enam) bulan di Indonesia adalah wajib untuk mendaftarkan dirinya sebagai anggota jaminan kesehatan nasional meskipun yang bersangkutan sudah memiliki jaminan kesehatan lain selain BPJS Kesehatan.

\section{Pelayanan kesehatan yang dilakukan kepada pasien peserta JKN harus memperhatikan mutu pelayanan dengan tujuan untuk memberikan keamanan pasien, efektifitas tindakan, dan kesesuaian dengan}

kebutuhan pasien agar terdapat kepastian terkait proses pelayanan kesehatan berjalan sesuai dengan standar yang ditetapkan. Sebagaimana ketentuan Permenkes Tentang Pelayanan Kesehatan Pada Jaminan Kesehatan Nasional Pasal 36 mengatakan bahwa kendali mutu dan kendali biaya pada tingkat faskes dilakukan oleh Faskes dan BPJS Kesehatan. Dilanjutkan Pasal 38 bahwa penyelenggaraan kendali mutu dan kendali biaya ini dilakukan melalui:

a. Pemenuhan standar mutu faskes;

b. Pemenuhan standar proses pelayanan kesehatan; dan

c. Pemantauan terhadap iuran kesehatan Peserta.

Dalam hal ini Undang-Undang Nomor 44 Tahun 2009 Tentang Rumah Sakit Pasal 15 menjelaskan bahwa rumah sakit harus memenuhi salah satu persyaratan kefarmasian yaitu menjamin ketersediaan sediaan farmasi dan alat kesehatan yang bermutu, bermanfaat, aman dan terjangkau. Sediaan farmasi memiliki peranan yang sangat penting dalam pelaksanaan program JKN. Maka, pelayanan kesehatan khususnya pelayanan obat yang diberikan haruslah bermutu, bermanfaat, aman dan terjangkau sehingga tujuan pemeliharaan kesehatan perorangan dan/atau masyarakat tercapai.

Ketentuan Peraturan Pemerintah Republik Indonesia Nomor 51 Tahun 2009 Tentang Pekerjaan Kefarmasiaan Pasal 1 angka 4 bahwa pelayanan kefarmasian adalah suatu pelayanan langsung dan bertanggung jawab kepada pasien berkaitan dengan sediaan farmasi dengan maksud mencapai hasil yang pasti untuk meningkatkan mutu kehidupan pasien. Pekerjaan kefarmasian ini dilakukan berdasarkan pada nilai ilmiah, keadilan,

kemanusiaan, keseimbangan, dan perlindungan serta keselamatan pasien atau masyarakat. Apotek sebagai suatu tempat dilakukannya pekerjaan kefarmasian dan penyaluran perbekalan farmasi kepada masyarakat. Berkaitan dengan hal tersebut, dalam melakukan pekerjaan kefarmasian, apoteker harus menetapkan Standar Prosedur Operasional (SPO) yang harus 
dibuat secara tertulis dan diperbaharui secara terus menerus untuk meningkatkan mutu pelayanan yang lebih baik. Tujuan pengaturan Pekerjaan Kefarmasian, antara lain: ${ }^{17}$

a. memberikan perlindungan kepada pasien dan masyarakat dalam memperoleh dan/atau menetapkan sediaan farmasi dan jasa kefarmasian;

b. mempertahankan dan meningkatkan mutu penyelenggaraan Pekerjaan

Kefarmasian sesuai dengan perkembangan ilmu pengetahuan dan tekonologi serta peraturan perundangan-undangan; dan

c. memberikan kepastian hukum bagi pasien, masyarakat dan Tenaga Kefarmasian.

Penyelenggaraan pelayanan obat dalam rangka pengamanan, pengadaan, penyimpanan dan pendistribusian obat, pelayanan obat atas resep dokter, pelayanan informasi obat serta pengembangan obat, bahan obat dan obat tradisional harus dilakukan oleh tenaga kesehatan yang mempunyai keahlian dan kewenangan sesuai dengan ketentuan perundang-undangan, dengan tujuan untuk menjaga penyalahgunaan farmasi yang dapat merugikan warga masyarakat. Untuk meningkatkan mutu pelayanan kesehatan sesuai kaidah dan standar yang berlaku diperlukan fornas sebagai bagian yang tidak terpisahkan dari INA CBG's. Melalui sistem ini FKRTL memberikan obat sesuai indikasi medis dan instalasi farmasi tidak bisa memberikan obat di luar dari jenis yang tercantum dalam fornas. Undang-Undang Kesehatan Pasal 98 secara tegas menjelaskan bahwa kesediaan farmasi dan

alat kesehatan harus aman, berkhasiat/bermanfaat, bermutu, dan terjangkau. Oleh sebab itu, setiap orang yang tidak memiliki keahlian dan

kewenangan dilarang mengadakan, menyimpan, mengolah, mempromosikan, dan mengedarkan obat dan bahan yang

17 Sudjana, Tanggung Jawab Pemerintah dan Obat Murah, Bandung:Keni Media, 2018, hlm 187. berkhasiat obat. Ketentuan mengenai pengadaan, penyimpanan, pengolahan, promosi, pengedaran sediaan farmasi harus memenuhi standar mutu pelayanan farmasi. Dalam praktik pelayanan obat merupakan

wewenang seorang apoteker yang menyerahkan obat-obatan semata-mata atas resep seorang dokter kepada pasien. Oleh sebab itu, apoteker memiliki kewajiban untuk menyerahkan obat sesuai dengan indikasi medis yang terdapat dalam resep dokter dan dipastikan terlaksana dengan baik untuk memenuhi kepastian hukum pasien peserta JKN.

Fornas disusun sebagai daftar obat yang digunakan sebagai acuan nasional dalam pelayanan kesehatan SJSN untuk menjamin aksesibilitas keterjangkauan dan penggunaan obat secara nasional juga bagi acuan bagi faskes dalam menjamin ketersediaan obat yang berkhasiat, bermutu, aman dan terjangkau dengan jenis dan jumlah yang cukup dalam sistem JKN.

Sehingga penyediaan obat esensial merupakan tanggung jawab pemerintah dan kewajiban bagi institusi pelayanan kesehatan baik publik maupun swasta. ${ }^{18}$ Kriteria obat yang tercantum dalam formularium nasional harus memiliki khasiat dan keamanan terbaik berdasarkan bukti ilmiah mutakhir dan valid. Obat-obatan yang tercantum dalam Fornas dengan harga terjangkau sudah teruji secara mutakhir dan dijamin pemerintah agar pelayanan kesehatan kepada masyarakat bisa dilaksanakan dengan sebaik-baiknya.

Terkait peran aktif perusahaan indutsri farmasi yang memproduksi obatobatan sebagai penyedia obat untuk menjalankan fungsinya tetap memerlukan kerjasama dengan stake holder seperti tenaga kesehatan, rumah sakit dan

puskesmas. Industri farmasi yang menghasilkan obat dapat mendistribusikan atau menyalurkan hasil produksinya langsung kepada pedagang besar farmasi, apotek, instalasi farmasi rumah sakit, pusat kesehatan masyarakat, klinik, dan toko obat

${ }^{18}$ Ibid, hlm. 6 
sesuai dengan ketentuan peraturan perundang-undangan. Dengan adanya kerjasama dimaksud, apotek rumah sakit diwajibkan untuk menjamin ketersediaan dan kecukupan obat, memberikan obat berdasarkan resep yang berpedoman pada fornas serta membuat dan melaporkan persediaan obat setiap bulan apabila terjadi kekosongan obat di faskes. Serta pedagang besar farmasi/pabrik obat dipastikan menjalankan sesuai kontrak kerjasama yang disepakati untuk menghindari kekosongan bahan obat, baik dalam proses produksi obat dan distribusi obat yang datang tepat waktu.

Faktanya yang terjadi di lapangan dalam pelaksanaan pemberian pelayanan kesehatan kepada pasien peserta JKN masih terdapat permasalahan seperti terdapat beberapa pasien peserta JKN yang mendapat pelayanan kurang optimal di faskes, hal ini dapat dilihat dari adanya kasus yang pernah terjadi dalam pemberian pelayanan kesehatan oleh beberapa faskes di

Kota Bandung. Diantaranya yaitu kekosongan stok obat yang telah dijamin oleh BPJS Kesehatan dan merupakan hak pasien peserta BPJS yang memenuhi kewajibannya untuk menerima obat tersebut yang telah diketahui bahwa obat merupakan bahan yang digunakan dalam menjalankan pelayanan kesehatan kuratif dengan tujuan untuk penyembuhan penyakit, pengurangan penderitaan akibat penyakit, pengendalian penyakit, atau pengendalian kecacatan agar kualitas penderita dapat terjaga seoptimal mungkin dan telah ditanggung oleh BPJS.

$$
\text { Kasus kedua mengenai }
$$

ketidakefektifan waktu yang dialami oleh pasien peserta JKN dalam mendapatkan antrian untuk memperoleh pelayanan kesehatan di fasilitas kesehatan wilayah Kota Bandung. Standar pelayanan minimal dalam faskes seperti rumah sakit dalam Menteri Kesehatan Republik Indonesia Nomr 129/menkes/SK II/2008 dalam bidang pelayanan farmasi waktu tunggu pelayanan obat jadi yaitu kurang dari 30 menit sedangkan obat racikan yaitu kurang dari 60 menit. Terdapat 2 jenis mekanisme antrian berdasarkan cara pengambilan nomornya yaitu melalui layanan pesan singkat atau short massage service (SMS) di faskes, jenis antrian ini dibuka mulai jam 04:00 - 10:00 sedangkan pada hari Jumat dan Sabtu dibuka mulai jam 04:00 - 09:30, namun antrian ini diperuntukkan bagi pasien yang telah memiliki Kartu Indentitas Berobat (KIB) dan berlaku pada hari tersebut saja. Yang kedua yaitu jenis antrian langsung dibuka mulai jam 06:15 - 10:00, antrian ini diperuntukkan untuk pasien yang belum memiliki KIB. Terkait cara pengambilan nomor antrian melalui SMS dibatasi jumlah pasien tiap harinya dan hanya yang

mendapatkan balasan yang dapat didaftarkan, sehingga pasien peserta JKN yang tidak dapat diprediksi jumlah setiap harinya datang ke faskes tidak akan terlayani seluruhnya. Berdasarkan hasil penelitian, Pihak RSUD pun menyadari kekurangan terkait tidak memadainya ruang pelayanan dan jumlah sumber daya medis yang relatif kurang mencukupi jika disandingkan dengan jumlah pasien, maka hal ini perlu dibenahi agar seluruh pihak tidak ada yang dirugikan.

Menurut Penulis bahwa pemberian pelayanan kesehatan khususnya pelayanan obat dan efektifitas pelayanan kesehatan terhadap pasien peserta JKN belum sepenuhnya memadai, disebabkan masih ditemukan hal-hal dalam pelayanan

kesehatan khususnya obat seperti kekosongan obat dalam apotek faskes dan jejaringnya sehingga menimbulkan masalah bahwa kebutuhan pasien peserta JKN tidak terpenuhi, juga terkait ketidakefektifan waktu yang ditempuh oleh kebanyakan pasien peserta JKN di faskes Kota Bandung. Serta mutu sarana produksi obat dinilai masih belum memadai, akibat kurang efektifnya pengawasan dan pembinaan. Obat yang dibutuhkan untuk pelayanan kesehatan terdapat beberapa stok yang tidak tersedia terutama obat-obat esensial seharusnya senantiasa tersedia. Juga efisiensi dan efektivitas sistem distribusi obat melalui regulasi yang tepat dan perlu ditingkatkan untuk menunjang ketersediaan, 
keterjangkauan dan pemerataan obat yang berkelanjutan.

Dalam pemenuhan hak atas pelayanan kesehatan masyarakat, pemerintah dalam ketentuan Permenkes Tentang Pelayanan Kesehatan Pada Jaminan Kesehatan Nasional menegaskan bahwa seluruh pasien seperta JKN telah dijamin haknya untuk mendapatkan pelayanan secara paripurna berupa pelayanan kuratif termasuk pelayanan obat sesuai dengan kebutuhan medis yang diperlukan dan memperoleh pelayanan yang efektif dan efisien sehingga pasien terhindar dari kerugian fisik dan materi. Sehingga apabila peserta JKN yang telah mengikuti prosedur dan ketentuan yang berlaku, serta pemberian resep obat dilakukan berdasarkan indikasi medis, maka pada kasus ini pasien penderita penyakit autoimmune wajib diberikan kepastian hukum berupa jaminan kepastian kesehatan dan pembiayaan. Dalam hal ini faskes tidak diperkenankan menarik iuran biaya peserta JKN terpisah, walaupun dengan alasan obat yang mampu dibeli harganya terjangkau dan pasien mampu beli diluar faskes, tetap tidak dibenarkan faskes meminta pasien JKN untuk menebus obat dengan biaya pribadinya sendiri. Selain itu, masih terdapat beberapa pasien yang tidak terpenuhi hak-haknya untuk mendapatkan pelayanan kesehatan yang efektif dan efisien seperti proses penanganan kesehatan yang membutuhkan waktu yang sangat lama di faskes, rata-rata total waktu yang dibutuhkan setelah mendapat surat rujukan dari FKTP harus melewati empat tahap antrian, antrian pertama untuk mendapat Surat Eligibilitas Peserta (SEP), antrian kedua di loket pendaftaran RS untuk mendapat medical record, antrian ketiga di poliklinik untuk mendapat pelayanan kesehatan dan antrian ke empat pemberian

obat, empat tahap ini rata-rata membutuhkan waktu hingga 8 jam per hari.

Berkaitan hal tersebut, aksesibilitas obat ditentukan oleh ketersediaan obat bagi pelayanan kesehatan. Kasus ini mencerminkan belum optimalnya manajemen logistik obat. Permenkes
Tentang Pelayanan Kesehatan pada Jaminan Kesehatan Nasional dalam Pasal 3 secara tegas menjelaskan bahwa pelayanan

kesehatan komprehensif termasuk pelayanan penunjang yang meliputi pemeriksaan laboratorium sederhana dan

pelayanan kefarmasian. Dalam pelaksanaannya apabila faskes tidak memiliki sarana penunjang wajib membangun jejaring dengan sarana penunjang. Maka, seharusnya apabila terjadi ketidaksediaan obat maka faskes tersebut wajib memiliki akses faskes lain melalui tujukan ke fasilitas penunjang lain untuk pemberian hak dalam memperoleh obat tersebut sesuai dengan indikasi medis. Selain itu, berdasarkan hasil wawancara dengan Penanggung Jawab Instansi Farmasi dan Pengadaan Obat Puskesmas Balai Kota Bandung, faskes dengan inisiatifnya membeli sendiri untuk menyediakan obat yang sedang mengalami kendala dari pihak ketiga, sehingga stok obat pun tersedia.

b. Perlindungan terhadap pasien dalam pelayanan kesehatan oleh fasilitas kesehatan yang bekerjasama dengan BPJS di Kota Bandung berdasarkan Undang_undang Nomor 24 Tahun 2011 dan Peraturan Menteri Kesehatan Nomor 71 Tahun 2013 tentan Pelayanan Kesehatan pada Jaminan Kesehatan Nasional

Undang-Undang Kesehatan Pasal 14 menjelaskan bahwa pemerintah bertanggung jawab merencanakan, mengatur, menyelenggarakan, membina, dan mengawasi penyelenggaraan upaya kesehatan yang merata dan terjangkau oleh masyarakat. Pembinaan sebagaimana dimaksud salah satunya memenuhi kebutuhan masyarakat untuk mendapatkan perbekalan kesehatan termasuk sediaan farmasi dan alat kesehatan. Juga Pasal 19 menjelaskan Pemerintah bertanggung jawab atas ketersediaan segala bentuk upaya kesehatan yang bermutu, aman, efisien, dan terjangkau. Berdasarkan hasil penelitian ${ }^{19}$,

\footnotetext{
${ }^{19}$ Berdasarkan hasil penelitian kepada Penanggung Jawab Instansi Farmasi dan Pengadaan Obat
} 
kekosongan stok obat memang lumrah terjadi setiap bulannya ini bahwa apoteker diperbolehkan mengganti obat merek dagang/obat paten atau obat generik yang tidak tersedia dengan obat merek dagang atau obat generik yang lain yang komponen aktifnya atau formulanya sama yang mana hal ini harus persetujuan dokter dan/atau pasien, namun tindakan ini tidak bisa dilakukan terhadap semua jenis obat sehingga apabila terdapat kasus obat tersebut tidak tersedia atau hanya merek tersebut yang dikonsumsi oleh pasien peserta JKN maka petugas kesehatan bagian farmasi memerintahkan pasien peserta JKN untuk membeli obat tersebut di luar faskes, hal ini yang tidak bisa dibenarkan sebab dalam hal sediaan farmasi seluruh pembiayaan obat telah dijamin oleh BPJS Kesehatan dan pasien peserta JKN tidak diperkenankan mengeluarkan biaya selain iuran yang dihimpun oleh BPJS Kesehatan setiap bulannya.

Menurut Undang-Undang Kesehatan Pasal 58 ayat (1) menjelaskan bahwa setiap orang berhak menuntut ganti rugi terhadap seseorang, tenaga kesehatan dan/atau

penyelenggara kesehatan yang menimbulkan kerugian akibat kesalahan atau kelalaian dalam pelayanan kesehatan yang diterimanya. Perjanjian merupakan persesuaian kehendak yang nyata antara dua orang atau lebih dengan maksud agar terjadinya suatu perikatan. Perikatan pada gilirannya mewajibkan seseorang menunaikan sesuatu dalam kasus ini menyelenggarakan pelayanan kesehatan. Pada saat pasien datang ke faskes yang dipilih baik rumah sakit maupun puskesmas secara tersirat akan membuat perjanjian terapeutik sesuai dengan Pasal 1313 KUHPerdata, hal ini dimaksudkan sebagai perikatan yang objeknya berupa upaya yang harus dilakukan dengan hati-hati dan usaha keras. ${ }^{20}$ Obyek perjanjian terapeutik terletak

Puskesmas Balai Kota Bandung pada 7 November 2019.

${ }^{20}$ Veronica Komalasari, Op.Cit, hlm. 143. pada upaya yang dilakukan untuk kesembuhan pasien (inspaning verbitenis). ${ }^{21}$

Kontrak terjadi saat telah melakukan diagnostik fisik oleh dokter dan memberikan resep. Resep yang ditulis kepada apoteker ditulis dengan jelas dan lengkap dan apotik harus menyerahkan obat sesuai dengan yang tertulis dalam resep. Kewajiban apoteker dalam melayani pasien berkaitan dengan resep harus sesuai dengan tanggung jawab dan keahlian profesinya yang dilandasi pada kepentingan pasien, apoteker pula tidak diizinkan untuk mengganti obat generik yang ditulis di dalam resep dengan obat paten, setelah itu apoteker memberikan informasi yang berkaitan dengan penggunaan obat yang akan diserahkan kepada pasien secara tepat, aman, dan rasional. Perikatan antara dokter dengan pasien, atau pasien dengan tenaga

kesehatan lain ini melahirkan suatu pertanggungjawaban secara hukum dalam bentuk perjanjian. Seharusnya kedua belah pihak saling memenuhi prestasi mengenai yang telah diperjanjikan namun pada kenyataannya terdapat kelalaian petugas kesehatan dikarenakan ada wanprestasi dalam pelayanan medis yang dilaksanakan. Hal ini menjadi tanggung jawab rumah sakit sebagai suatu badan hukum yang bertanggung jawab secara perdata terhadap semua kegiatan yang dilakukan oleh tenaga kesehatan sesuai dengan 1365 KUHPerdata dapat dituntut atas kerugian secara langsung sebagai pihak sebab terdapat suatu perjanjian yang wanprestasi (ingkar janji). Menurut Pasal 1234 KUHPerdata prestasi dibagi menjadi 3, antara lain: a. Memberikan sesuatu, b. Berbuat sesuatu, dan c. Tidak berbuat sesuatu. Berdasarkan hal tersebut jika dikaitkan kasus yang diangkat berkaitan dengan prestasi berbuat sesuatu atau melakukan sesuatu yang

seharusnya dilakukan oleh bidang kefarmasian kepada pasien dalam perjanjian namun perbuatan jasa ini tidak

\footnotetext{
${ }^{21}$ Desriza Ratman, Aspek Hukum Penyelenggaraan Praktek Kedokteran dan Malpraktek Medik, Bandung: Keni Media, 2014, hlm. 17.
} 
dilaksanakan. Pada hakekatnya merupakan hak pasien untuk menerima pelayanan medis. Apabila prestasi ini tidak dilaksanakan maka tidak akan terwujud tujuan pembangunan kesehatan untuk mencapai derajat kesehatan masyarakat yang optimal disebabkan terdapat beberapa pasien yang tidak terpenuhi hak-haknya. Berdasarkan hasil wawancara, ditinjau dari pelaksanaannya hak dan kewajiban pasien, tanggung jawab faskes sebagai pihak penyelenggara pelayanan kesehatan yang secara langsung melakukan tindakan medis maka dasar perlindungan hukum bagi pasien peserta JKN adalah berbagai tindakan untuk menjamin terlaksananya kepastian hukum kepada peserta dalam mendapatkan pelayanan kesehatan. Jika terdapat tenaga kesehatan di faskes yang tidak dapat memenuhi prestasinya atau tidak memenuhi kewajibannya karena ada unsur kesalahan padanya.

Kesalahan ini berhubungan dengan ruang lingkup medis jelas terlihat adanya suatu motif dari tenaga kesehatan yang merugikan pasien sehingga terdapat pertanggungjawaban atas perbuatannya. Tidak terpenuhinya prestasi oleh faskes disebut juga dengan wanprestasi, yang disebabkan karena adanya kelalaian oleh salah satu tenaga kesehatan. Pasien peserta

JKN-KIS dapat memilih tuntutan sebagaimana disebutkan dalam Pasal 1267

KUHPerdata, yaitu: a. Pemenuhan perikatan; b. Pemenuhan perikatan dengan ganti kerugian; c. Ganti kerugian; d. Pembatalan perjanjian timbal balik. Bentuk perlindungan pasien dalam hal tanggung jawab yang didasarkan pada tindakan wanprestasi akibat dari tidak terpenuhinya kewajiban utama atau kewajiban tambahan yang berupa kewajiban atas prestasi utama atau kewajiban jaminan/garansi dalam perjanjian dapat berupa bentuk pemenuhan perikatan dengan diwujudkan dengan tindakan nyata memberi pelayanan secara efektif dan efisien.

Pasal 1365 KUHPerdata menegaskan tiap perbuatan melanggar hukum yang membawa kerugian kepada orang lain, mewajibkan orang yang karena salahnya menerbitkan kerugian itu mengganti kerugian tersebut. Selanjutnya Pasal 1367 jo. Pasal 1366 KUHPerdata, bahwa seseorang tidak hanya bertanggung jawab atas kerugian yang disebabkan perbuatannya sendiri melainkan juga atas kerugian yang disebabkan perbuatanperbuatan orang-orang yang menjadi tanggungannya atau disebabkan benda yang berada di bawah pengawasannya. Maka rumah sakit dan apoteker bertanggung jawab untuk membayar ganti rugi terkait kerugian yang diderita pasien.

Bahwa setiap orang ini bertangung jawab bukan hanya atas kerugian yang disebabkan perbuatan-perbuatan, melainkan juga atas kerugian yang disebabkan kelalaiannya, hal tersebut jelas bertentangan dengan asas hukum yang mendasari pelayanan kesehatan yaitu asas tepat waktu sehingga menimbulkan kerugian pada pasien, hal ini kerugian materiil berupa dana yang dikeluarkan untuk pembelian obat diluar apotek RS pada kasus pertama dan kerugian immaterial berupa waktu yang membuat pasien tidak dapat bekerja dan tenaga pasien peserta JKN dalam 3 hari berturut-turut datang ke faskes namun tetap tidak dipenuhi pelayanannya. UndangUndang Kesehatan Pasal 29 menjelaskan bahwa dalam hal tenaga kesehatan diduga melakukan kelalaian dalam menjalankan profesinya, kelalaian tersebut harus diselesaikan terlebih dahulu melalui mediasi. Berkaitan dengan hal ini yaitu malpraktek perdata saja yang boleh dilakukan mediasi sehingga penyelesaian sengketa medik tidak berlanjut ke tingkat pengadilan. Pelanggaran atas kewajiban-

kewajiban RS dikenakan sanksi administratif berupa: teguran, b. teguran tertulis; atau c. Denda dan pencabutan izin Rumah Sakit. Dalam Undang-Undang Kesehatan Pasal 201 diatur mengenai ketentuan pidana kepada korporasi dapat dijatuhi pidana tambahan berupa:

a. Pencabutan izin usaha;dan/atau

b. Pencabutan status badan hukum. 
Undang-Undang Rumah Sakit Pasal 27, mengatakan bahwa izin rumah sakit dapat dicabut salah satunya apabila tidak lagi memenuhi persyaratan dan standar dan terbukti melakukan pelanggaran terhadap peraturan perundang-undangan. Dalam Pasal 46 Undang-Undang Rumah Sakit pula dijelaskan bahwa rumah sakit bertanggung jawab secara hukum apabila kerugian yang ditimbulkan dilakukan oleh tenaga kesehatan. Pemberi pelayanan harus menjaga mutu pelayanan, perubahan sistem yang cepat belum dapat diadaptasi oleh pemberi pelayanan, terutama pemberlakuan cara pembayaran prospektif dengan INA CBG's, serta implikasinya terhadap pentingnya meningkatkan efisiensi. BPJS dalam kasus ini diperlukan pengawasan terkait tindakan kelalaian atau potensi fraud petugas kesehatan tersebut. Sebab secara hukum tindakan tersebut tidak dibenarkan. Berdasarkan hasil wawancara Kepala Bidang Penjaminan Manfaat Rujukan Klinik Utama dan Rumah Sakit BPJS Kesehatan Cabang Bandung pada prinsipnya pelayanan obat dan daftar obat sudah sepakat menjadi kesatuan di formularium nasional, bahkan obat yang diluar fornas tetap menjadi tanggung jawab faskes. Jadi, pengadaan obat mutlak menjadi ranah tanggung jawab

faskes, baik pengadaannya dan penyediannya, resiko terkait informasi dan kekosongan obat. Sehingga BPJS Kesehatan diperlukan tindakan pengawasan dan penanganan terhadap berbagai keluhan peserta dalam pelaksanaan pelayanan kesehatan. $^{22}$

Pasien peserta JKN yang merasa dirugikan dalam pelayanan kesehatan yang diselenggarakan oleh faskes dapat meminta hak-haknya sesuai dengan ketentuan dalam peraturan perundang-undangan. Dalam hal meminta hak-haknya, berbentuk ganti rugi apabila memperoleh pelayanan kesehatan oleh faskes yang bekerjasama dengan BPJS

22 Berdasarkan hasil penelitian Kepala Bidang Penjaminan Manfaat Rujukan Klinik Utama dan Rumah Sakit BPJS Kesehatan Cabang Bandung pada 1 November 2019. tidak sesuai dengan peraturan yang berlaku. Dalam hukum perdata sanksi yang diterapkan berbentuk ganti kerugian yang diberikan oleh pelaku usaha kepada pasien/konsumen yang dirugikan, yaitu berupa pengembalian uang, maupun penggantian barang dan/atau jasa, perawatan kesehatan ataupun pemberian santunan. Maka bentuk upaya hukum yang tersedia

bagi pasien peserta JKN adalah penyelesaian sengketa berdasarkan proses peradilan. Pihak yang dirugikan dapat menggugat dan/atau menuntut petugas kesehatan atau Rumah Sakit baik secara perdata maupun pidana melalui proses hukum yang belaku. Pengaduan perdata dapat diajukan pasien ke pengadilan berdasarkan kerugian yang dialaminya. Keputusan dari pengadilan bersifat mengikat. Upaya yang dapat dilakukan bagi pasien peserta JKN bagi pemegang kartu BPJS Kesehatan yang merasa dirugikan atau ketidakpuasan dalam pelayanan kesehatan dapat melakukan upaya keluhan dengan menghubungi call center BPJS 1500400 atau datang langsung ke kantor cabang BPJS Kesehatan terdekat. Dalam Undang-Undang BPJS Pasal 48 dibentuk unit pengendali mutu pelayanan dan penanganan pengaduan Peserta. Sehingga bagi pasien peserta JKN yang merasa dirugikan hak-haknya dapat melakukan pengaduan, jika pihak yang merasa dirugikan yang pengaduannya belum dapat diselesaikan oleh unit, maka penyelesaian sengketanya dapat dilakukan melalui mekanisme mediasi. Bantuan mediator yang disepakati oleh kedua belah pihak secara tertulis. Penyelesaian sengketa melalui mekanisme mediasi, setelah ada kesepakatan kedua belah pihak secara tertulis bersifat final dan mengikat. Tetapi apabila pengaduan oleh unit pengendali mutu pelayanan dan penanganan pengaduan Peserta JKN melalui mekanisme mediasi tidak dapat terlaksana, penyelesaiannya dapat diajukan ke pengadilan negeri di wilayah tempat tinggal pemohon. 


\section{KESIMPULAN}

Pemberian pelayanan kesehatan khususnya pelayanan obat dan efektifitas pelayanan kesehatan terhadap pasien peserta JKN di beberapa faskes Kota Bandung berdasarkan hasil penelitian di Puskesmas Garuda, Puskesmas Balai Kota Bandung dan Puskesmas Caringin belum sepenuhnya memadai belum sepenuhnya memadai, disebabkan masih ditemukan hal-hal dalam pelayanan kesehatan khususnya obat seperti kekosongan obat dalam apotik faskes dan jejaringnya, juga terkait ketidakefetifan waktu yang ditempuh oleh kebanyakan pasien peserta JKN untuk mendapatkan pelayanan kesehatan. Dalam pelayanan kesehatan manfaat yang dijamin berupa pelayanan kesehatan perorangan, mencakup pelayanan promotif, preventif, kuratif, dan rehabilitatif, termasuk pelayanan obat, alat kesehatan, dan bahan medis habis pakai sesuai dengan kebutuhan medis yang diperlukan.

Perlindungan hukum terhadap pasien dalam Undang-Undang Kesehatan telah dijamin terkait kerugian akibat kesalahan atau kelalaian dalam pelayanan kesehatan yang diterimanya. Upaya yang dapat dilakukan bagi pasien peserta JKN bagi pemegang kartu BPJS Kesehatan yang merasa dirugikan atau ketidakpuasan dalam pelayanan kesehatan dapat melakukan upaya keluhan ke kantor cabang BPJS Kesehatan terdekat, melalui unit pengendali mutu pelayanan dan penanganan pengaduan peserta, apabila belum dapat diselesaikan oleh unit, maka penyelesaian sengketanya dapat dilakukan melalui mekanisme mediasi. Jika tetap tidak terlaksana penyelesaiannya dapat diajukan ke pengadilan negeri di wilayah tempat tinggal pemohon. Dasar hukum bagi faskes untuk memberikan ganti akibat kelalaiannya berdasarkan Pasal 1365 jo Pasal 1366 jo Pasal 1367 KUHPerdata, sehingga bidang kefarmasian di faskes tersebut akan diwakili oleh faskes yang bersangkutan, serta Pasal

46 Undang-Undang Rumah Sakit pula dijelaskan bahwa rumah sakit bertanggung jawab secara hukum apabila kerugian yang ditimbulkan dilakukan oleh tenaga kesehatan.

\section{DAFTAR PUSTAKA}

AzrulAnwar, Pengantar Administrasi Kesehatan, Jakarta: Binarupa Aksara, 2010

Desriza Ratman, Aspek Hukum Penyelenggaraan Praktek Kedokteran dan Malpraktek Medik, Bandung: Keni Media, 2014.

Hermien Hadiati Koeswadji, Hukum Untuk Perumahsakitan, Bandung: PT. Citra Aditya Bakti, 2002.

Sudjana, Tanggung Jawab Pemerintah dan Obat Murah, Bandung: Keni Media, 2018.

Sulastomo, Sistem Jaminan Sosial Nasional Mewujudkan Amanat Konstitusi, Jakarta:PT Kompas Media Nusantara, 2011.

Veronika Komalawati, Peranan Informed Consent Dalam Transaksi Terapeutik, Bandung:PT Citra Aditya Bakti, 2002.

\section{Peraturan Perundang-Undangan:}

Kitab Undang-Undang Hukum Perdata (Burgerlijk Wetboek)

Undang-Undang Dasar Republik Indonesia Tahun 1945 Amandemen Ke IV

Undang-Undang Nomor 40 Tahun 2004 Tentang Sistem Jaminan Sosial Nasional

Undang-Undang Nomor 36 Tahun 2009 Tentang Kesehatan

Undang-Undang Nomor 44 Tahun 2009 Tentang Rumah Sakit

Undang-Undang Nomor 24 Tahun 2011 Tentang Badan Penyelenggara Jaminan Sosial

Peraturan Pemerintah Republik Indonesia Nomor 51 Tahun 2009 Tentang Pekerjaan Kefarmasiaan

Peraturan Menteri Kesehatan Nomor 71 Tahun 2013 Tentang Pelayanan Kesehatan Pada Jaminan Kesehatan Nasional 
Peraturan Pemerintah Republik Indonesia Nomor 47 Tahun 2016 Tentang Fasilitas Pelayanan Kesehatan

\section{Sumber lain:}

https://bpjs-

kesehatan.go.id/bpjs/index.php/page

s/detail/2017/27, diakses pada 13 September 2019, 7:33 WIB.

"Pelayanan

RSUD”,

https://www.lapor.go.id/laporan/detil /pelayanan-rsud-26, diakses pada 31 Juli 2019, 10:27 WIB.

"Kelangkaan Obat Sulfalazine di RS negara", https://www.lapor.go.id/laporan/detil/ kelangkaan-obat-sulfasalazine-di-rsnegara, diakses pada 18 Juli 2019, 9:15 WIB.

"Keberadaan Obat Deferoxamine Yang Langka",

https://www.lapor.go.id/profil/177661 4, diakses pada 18 Juli 9:19 WIB.

"Hak dan Kewajiban", https://bpjskesehatan.go.id/bpjs/index.php/pages/ detail/2017/27, diakses pada $10 \mathrm{Juli}$ 2019, 15:18 WIB 